\begin{tabular}{|l|l|l|}
\hline Received : 03/05/2021 & Accepted: 20/06/2021 & Published : 30/06/2021 \\
\hline
\end{tabular}

\title{
Optimalisasi Kadar Asam Asetat Ananas Comosus I dengan Penambahan Induk Cuka
}

\author{
Fitria Fitria $^{1)}$, Mimin Septiani ${ }^{2}$, Irhamni Nuhardin ${ }^{3)}$ \\ ${ }^{1-3}$ Program Studi Teknik Kimia Sekolah Tinggi Teknologi Industri Bontang. \\ Jl. Bridgjen KatamsoNo. 40 Bontang - Indonesia 75311 \\ (Email: tekimfitria@gmail.com)
}

\begin{abstract}
Ananas comosus L. (Pineapple) is one of the superior fruit commodities in Indonesia. The amount of production in 2016 pineapples placed fourth after bananas, oranges and mangoes which amounted to 1.4 million tons/year. Pineapple production for East Kalimantan, Balikpapan city has an area of 8,572 hectares of pineapple with a production of 7,206 tons of pineapple. Pineapple skin contains $17.53 \%$ carbohydrates and $13.65 \%$ sugar. This led researchers to develop the manufacture of acetic acid from the skin waste of Ananas comosus L. The research method consists of materials used namely, pineapple skin, water, granulated sugar, yeast, vinegar, ammonium sulfate, oxalic acid, sodium hydroxide, pp indicators and aquades obtained from STTI Bontang laboratory. The working procedure of this study consists of 3 stages of the method: the first fermentation stage with the addition of Saccharomyces cerevisiae, the second fermentation stage with variations in the addition of the parent vinegar and the calculation of acetic acid levels with time intervals of 2 days /sample (days 16, 18,20, 22 and 24). The third stage is carried out by alkaline method. Optimum results from research with the main variation of vinegar and fermentation time were obtained on the 20th day with the addition of a $2.3 \mathrm{~mL}$ vinegar master obtained a acetic acid content of $6.24 \mathrm{~g} / \mathrm{mL}$. Further researchers are expected to develop better analytical methods to make the concentration of acetic acid obtained more optimal.
\end{abstract}

Keywords : Ananas comosus, acetic acid, fermentation, parent vinegar, Saccharomyces cerevisiae

\begin{abstract}
Abstrak
Ananas comosus L. (Nanas) merupakan salah satu komoditas buah yang unggul di Indonesia. Besarnya produksi pada tahun 2016 nanas menempati posisi keempat setelah buah pisang, jeruk dan mangga yaitu sebesar 1,4 juta ton/tahun. Produksi buah nanas untuk wilayah Kalimantan Timur, kota Balikpapan memiliki luas area tanaman buah nanas 8.572 hektar dengan produksi 7.206 ton nanas. Kulit nanas mengandung 17,53 \% karbohidrat dan 13,65 \% gula. Hal ini yang menyebabkan peneliti ingin mengembangkan pembuatan asam asetat dari limbah kulit Ananas comosus L. Metode penelitian terdiri dari bahan yang digunakan yaitu, kulit nanas, air, gula pasir, ragi, cuka, amonium sulfat, asam oksalat, natrium hidroksida, indikator pp dan aquades yang diperoleh dari laboratorium STTI Bontang. Prosedur kerja dari penelitian ini terdiri dari 3 tahapan metode : tahap fermentasi pertama dengan penambahan Saccharomyces cerevisiae, tahap fermentasi kedua dengan variasi penambahan induk cuka dan perhitungan kadar asam asetat dengan interval waktu 2 hari/sampel (hari 16, 18, 20, 22 dan 24). Tahap ketiga dilakukan dengan metode adisi alkalimetri. Hasil optimum dari penelitian dengan variasi induk cuka dan waktu fermentasi didapatkan pada hari ke-20 dengan penambahan induk cuka 2,3 $\mathrm{mL}$ diperoleh kadar asam asetat sebesar $6,24 \mathrm{~g} / \mathrm{mL}$. Peneliti berikutnya diharapkan mampu mengembangkan metode analisa lebih baik agar konsentrasi asam asetat yang diperoleh lebih optimal.
\end{abstract}

Kata kunci : Ananas comosus, asam asetat, fermentasi, induk cuka, Saccharomyces cerevisiae

\section{Pendahuluan}

Asam asetat merupakan senyawa organik yang mengandung gugus asam karboksilat, yang diketahui sebagai pemberi rasa asam dan aroma dalam makanan [1]. Asam asetat dihasilkan dari berbagai bahan yang memiliki glukosa dan pati melalui proses fermentasi 
alkohol yang disertai fermentasi asetat [2]. Sebelum menjadi asam asetat, gula yang terdapat dalam bahan alami terlebih dahulu diubah menjadi etanol dengan bantuan ragi, kemudian etanol dioksidasi menjadi asam asetat [3]. Beberapa bahan baku alami yang dapat digunakan dalam pembuatan asam asetat, diantaranya, salak dan pisang [4], buah mangrove pedada [5], kulit durian [3], pepaya burung [6], air kelapa [7] dan kulit nanas [8]. Metode fermentasi maupun hidrolisis zat berupa polimer glukosa pada bahan-bahan alami dapat menghasilkan produk berupa asam asetat.

Pada penelitian ini kami menggunakan bahan baku kulit nanas. Nanas (Ananas comosus L.) merupakan salah satu komoditas buah unggulan di Indonesia. Nanas dimanfaatkan masyarakat Indonesia dalam sektor pangan, selain dapat dikonsumsi langsung nanas juga dapat dijadikan bahan olahan [9] seperti di industri makanan maupun minuman [10]. Di Provinsi Kalimantan Timur, luas lahan petani yang digunakan untuk ditanami nanas seluas 8,572 hektar dengan produksi 7.206 ton/tahun [8].

Menurut data Badan Pusat Statistik Indonesia produksi nanas periode 2016-2017 sebesar 1,4 juta ton/tahun [11]. Menurut Wijana, et al, 1991 [12] , dalam kutipan [13], Kulit nanas mengandung 81,71 air, 20,87\% serat kasar, 17,53 \% karbohidrat dan 13,65\% gula dan $4,41 \%$ protein. Kulit nanas memiliki kandungan glukosa dari golongan polisakarida. Karbohidrat merupakan substansi yang dibutuhkan untuk reaksi fermentasi alkohol kemudian difermentasikan menjadi asam asetat [14]. Menurut [15] lama fermentasi alami secara aerob pulp kakao terhadap karakteristik cuka fermentasi dengan menggunakan aerator berupa pompa air aquarium selama 10 hari dan menghasilkan kadar asam astat tertinggi sebanyak 2, 30\% (v/v) dari lama fermentasi 6 hari.

\section{Tinjauan Teori}

Proses Pembuatan asam asetat memerlukan dua tahapan fermentasi yaitu:

a. Perubahan glukosa menjadi alkohol oleh khamir

b. Perubahan alkohol menjadi cuka

Fermentasi ada tiga yaitu: [16]

1. Fermentasi alkohol

Fermentasi alkohol merupakan suatu reaksi pengubahan glukosa menjadi etanol (etil alkohol) dan karbondioksida. Saccaharomyces cerevisiae (ragi) adalah organisme yang digunakan dalam proses fermentasi. Reaksi Kimia:

$\mathrm{C}_{6} \mathrm{H}_{12} \mathrm{O}_{6} \rightarrow 2 \mathrm{C}_{2} \mathrm{H}_{5} \mathrm{OH}+2 \mathrm{CO}_{2}+2 \mathrm{ATP}$

1. Fermentasi asam laktat merupakan respirasi yang terjadi pada sel hewan atau manusia, dimana terjadi ketika kebutuhan oksigen tidak mencukupi akibat kerja terlalu berat. Glukosa dipecah menjadi 2 molekul asam piruvat melalui glikolisis, membentuk 2 ATP dan 2NADH.

2. Fermentasi pembentukan asam cuka berlangsung secara aerob dilakukan oleh bakteri Acetobacter aceti dengan substrat etanol. Energi yang dihasilkan dari fermentasi aerob 5 kali lebih besar dari energi yang dihasilkan oleh fermentasi anaerob.

Teknik Analisa kadar asam asetat

Analisa kadar asam asetat pada kulit buah nanas dilakukan dengan metode adisi alkalimetri dengan larutan standar $\mathrm{NaOH} 0,1 \mathrm{~N}$, dimana $10 \mathrm{~mL}$ larutan cuka diencerkan dalam $250 \mathrm{~mL}$ dilakukan titrasi sebanyak 3 kali. Kadar asam asetat diperoleh dari persamaan : 


$$
\begin{aligned}
& \frac{1}{1000} \times \frac{100}{V i} \times F p \times C_{N a o H} \times V_{t} \times M r_{\text {asetat }} \\
& F p=\frac{\text { Volume Total pengenceran }}{\text { Volume sampel }}
\end{aligned}
$$

Ket :

$\mathrm{Vi}=$ Volume induk cuka $(\mathrm{ml})$

$\mathrm{Fp}=$ Faktor Pengenceran $(\mathrm{ml})$

$\mathrm{C}=$ Konsentrasi $(\mathrm{N})$

$\mathrm{Vt}=$ Volume titran $(\mathrm{ml})$

$\mathrm{Mr}=$ Massa Relatif $(\mathrm{gram} / \mathrm{mol})$

\section{Metoda Penelitian}

Alat dan Bahan

Alat yang digunakan dalam penelitian ini meliputi kulit nanas, pisau dan talenan untuk merajang kulit nanas, panci dan kompor digunakan untuk merebus kulit nanas, gelas plastik sebagai tempat permentasi, saringan, corong, penyaring, buret, erlenmeyer, tiang statif, labu ukur 50\% mL 250\% mL, dan pipet ukur. Bahan yang dibutuhkan adalah kulit nanas, Air, Gula Pasir, Ragi, Cuka, Amonium Sulfat $\left.\left(\mathrm{NH}_{4}\right)_{2} \mathrm{SO}_{4}\right)_{(\mathrm{s})}$, Asam Oksalat $\left(\mathrm{C}_{2} \mathrm{H}_{2} \mathrm{O}_{4}\right)_{(\mathrm{s})}$, Natrium Hidroksida $(\mathrm{NaOH})_{(a q)}$, Indikator PP dan Aquades yang diperoleh dari Laboratorium STTI Bontang.

Prosedur Fermentasi

Metode ekperimen penambahan induk cuka $(0 \mathrm{~mL}, 1,6 \mathrm{~mL}$ dan 2,3 $\mathrm{mL})$ dan lama fermentasi (16 hari, 18 hari, 20 hari, 22 hari dan 24 hari) pada fermentasi kulit buah nanas.

Mecacah dan menimbang kulit buah nanas sebanyak $0,5 \mathrm{~kg}$, lalu direbus dengan air 1 liter hingga mendidih. Hasil rebusan kulit nanas kemudian didinginkan dan disaring.

Pada penelitian ini menggunakan dua tahap fermentasi:

Fermentasi I

Hasil rebusan yang telah disaring diambil sekitar $500 \mathrm{~mL}$, melakukan penambahan gula pasir 15 gram sebagai konsumsi untuk mikroorganisme dan ammonium sulfat 0,9 gram pada suhu kamar. Mikroorganisme yang tambahkan berupa ragi (Saccharomices cereviceae) sebanyak 3,75 gram.

Proses fermentasi pertama berlangsung selama dua minggu (14 hari), proses mangubah larutan kulit nanas menjadi larutan alkohol. Pada proses ini mengubah sari dari kulit nanas menjadi alkohol.

Fermentasi II

Hasil fermentasi I kemudian ditambahkan larutan induk cuka dengan variasi $0 \mathrm{~mL}, 1,6 \mathrm{~mL}$ dan 2,3 mL, dan menghitung kadar asam asetat dengan variasi selang waktu 2 hari/sampel (hari ke $16,18,20,22$ dan hari 24) untuk mengetahui kadar asam asetat yang dihasilkan dilakukan dengan menitrasi .

\section{Hasil Penelitian}

Perlakuan awal yang dilakukan adalah standarisasi larutan $\mathrm{NaOH}$ dengan larutan asam oksalat. Hasil standarisasi larutan $\mathrm{NaOH}$ dengan larutan standar asam oksalat ditunjukkan pada tabel 1 
Tabel 1. Volume Standarisasi NaOH 0,1 N dengan Asam Oksalat

\begin{tabular}{cc}
\hline No. & $\begin{array}{c}\text { Larutan } \mathbf{N a O H ~ 0 , 1 ~ N} \\
(\mathbf{m l})\end{array}$ \\
\hline $\mathbf{1}$ & 7,7 \\
$\mathbf{2}$ & 7,6 \\
$\mathbf{3}$ & 7,8 \\
Vol. rata- & 7,7 \\
rata & \\
\hline
\end{tabular}

Dari tabel 1 hasil standarisasi didapatkan konsentrasi $\mathrm{NaOH} \mathrm{0,073 \textrm {N }}$.

Hasil standarisasi volume larutan $\mathrm{NaOH}$ digunakan untuk menitrasi hasil fermentasi 2 ditunjukkan pada tabel 2.

Tabel.2 Volume Titrasi $\mathrm{NaOH}$

\begin{tabular}{|c|c|c|c|c|}
\hline \multirow[t]{4}{*}{ No } & \multirow{4}{*}{$\begin{array}{l}\text { Waktu } \\
\text { Fermentasi } \\
\text { (Hari ke) }\end{array}$} & \multicolumn{3}{|c|}{ Titrasi Sampel } \\
\hline & & Tanpa & Induk & Induk \\
\hline & & Induk & Cuka & Cuka \\
\hline & & $\begin{array}{l}\text { Cuka } \\
\text { (ml) }\end{array}$ & $\begin{array}{l}1,6 \mathrm{ml} \\
(\mathrm{ml})\end{array}$ & $\begin{array}{l}2,3 \mathrm{ml} \\
(\mathrm{ml})\end{array}$ \\
\hline 1 & 16 & 5,5 & 6,3 & 8,6 \\
\hline 2 & 18 & 7,4 & 8,9 & 10,2 \\
\hline 3 & 20 & 8,4 & 9,7 & 11,4 \\
\hline 4 & 22 & 7,8 & 9,0 & 11,3 \\
\hline 5 & 24 & 7,7 & 8,1 & 11,1 \\
\hline
\end{tabular}

Hasil analisis menunjukkan bahwa penambahan induk cuka dan waktu fermentasi dapat dilihat dari hasil standarisasi $\mathrm{NaOH}$ menghasilkan konsentrasi terbaik pada waktu fermentasi hari ke 20, penambahan induk cuka dengan konsentrasi $2,3 \mathrm{ml}$ menghasilkan volume titrasi $\mathrm{NaOH}$ $11,4 \mathrm{ml}$. Hal ini menunjukkan bahwa semakin tinggi kadar asam asetat, maka semakin besar volum $\mathrm{NaOH}$ yang digunakan dalam titrasi sampel.

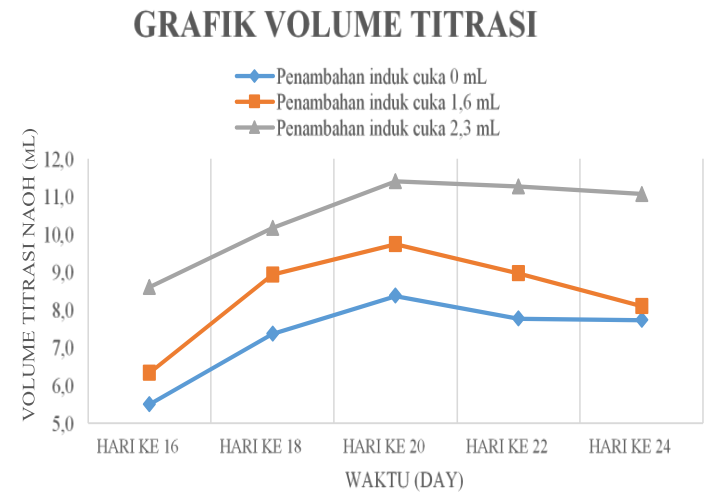

Gambar.1 Grafik hubungan antara waktu fermentasi dan Volume titran 
Gambar 1 Hasil perbandingan antara waktu fermentasi dan volume titrasi waktu optimum adalah hari ke 20. Hal ini disebabkan oleh aktivitas bakteri acetobacter aceti yang merombak alkohol menjadi asam cuka menjadi lebih banyak seiring bertambahnya waktu fermentasi [17], Sehingga pada hari ke-20 dicapai laju fermentasi yang optimum. Setelah hari ke-20 laju fermentasi mengalami penurunan yang disebabkan karena asupan glokusa dan ammonium sulfat pada bakteri untuk memecah asam organik pada sari pati kulit nanas telah berkurang, akibatnya kadar alkohol yang dibutuhkan sebagai medium penghasil asam asetat juga menurun.

Tabel 3. Kadar Asam Asetat

\begin{tabular}{llllr}
\hline No & Waktu & \multicolumn{3}{c}{ Kadar Asam Asetat } \\
& Fermentasi & \multicolumn{3}{c}{ (mg/l) } \\
\cline { 3 - 5 } & & $0 \mathrm{ml}$ & $1,6 \mathrm{ml}$ & $2,3 \mathrm{ml}$ \\
& & & & \\
1 & Hari ke 16 & 3,01 & 3,45 & 4,71 \\
2 & Hari ke 18 & 4,05 & 4,87 & 5,58 \\
3 & Hari ke 20 & 4,59 & 5,31 & 6,24 \\
4 & Hari ke 22 & 4,27 & 4,93 & 6,19 \\
5 & Hari ke 24 & 4,22 & 4,43 & 6,08 \\
\hline
\end{tabular}

Tabel 3 menunjukkan kadar asam asetat yang dihasilkan setelah melewati tahap fermentasi. Kadar asam asetat yang optimal diperoleh pada hari ke 20. Variabel tanpa penambahan induk cuka, menghasilkan kadar asam asetat sebesar 4,59 mg/l, dengan penambahan 1,6 ml cuka sebesar 5,31 $\mathrm{mg} / \mathrm{l}$ dan penambahan 2,3 ml sebesar 6,24 mg/l. Kadar ini masih sesuai dengan SNI 01-4371-1996 tentang cuka fermentasi dengan kadar minimum 4mg/100 ml dan SNI 01-3711-1995 tentang cuka makan dengan kadar $4-12,5 \%(b / b)$.

Setelah hari ke 20 jumlah kadar asam asetat $0 \mathrm{ml}$ sebesar 4,59 mg/1, 1,6 ml sebesar 5,31 mg/1 dan 2,3 ml sebesar $6,24 \mathrm{mg} / 1$ kondisi media fermentasi sudah tidak mendukung aktifitas bakteri dapat dilihat dari jumlah kadar asam asetat pada hari ke 22 dan hari ke 24, sebagian bakteri telah mati sehingga kadar asam asetat ikut menurun. Fermentasi yang terlalu lama juga mengakibatkan asam asetat mengalami oksidasi atau terurai oleh oksigen dari udara menjadi CO2 dan H2O [1]

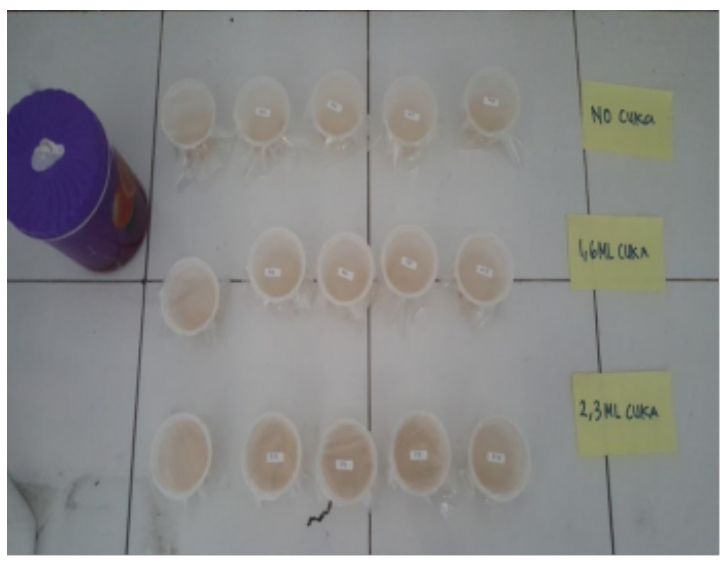

Gambar.2 Larutan Hasil Fermentasi 
Dari gambar 2 dapat dilihat pengamatan secara visual setelah proses fermentasi selama 3 minggu, berupa warna, aroma, dan penampakan yang hampir sama.

\section{Kesimpulan}

Kadar asam asetat yang dihasilkan dari kulit nanas dengan variasi waktu dan penambahan induk cuka didapatkan pada hari ke-20 dengan penambahan induk cuka 2,3 mL diperoleh kadar asam asetat sebesar 6,24 g/ml. Kadar asam asetat yang dihasilkan telah sesuai SNI 01-43711996 tentang cuka fermentasi dan SNI 01-3711-1995 tentang cuka makan.

\section{Daftar Pustaka}

[1] W. Wusnah, M. Meriatna, and R. Lestari, "Pembuatan Asam Asetat dari Air Cucian Kopi Robusta dan Arabika dengan Proses Fermentasi," J. Teknol. Kim. Unimal, vol. 1, no. Mei, pp. 61-72, 2018.

[2] J. Sarjana et al., "BESERTA KULITNYA TEKNIK FERMENTASI * Email : dwidanafebriani@gmail.com,”vol.2,no.2, pp.73-78, 2018.

[3] I. Irhamni, D. Diana, S. Saudah, E. Ernilasari, and M. A. Suzanni, "Fermentasi Limbah Kulit Durian Menjadi Cuka Organik Dengan Menggunakan Acetobacter aceti. Elkawnie.," 2019, doi: 10.22373/ekw.v5i1.3902.

[4] D. . Febriani and Z. Azizati, "Pembuatan Cuka Alami Buah Salak Dan Pisang Kepok Beserta Kulitnya Teknik Fermentasi," Walisongo J. Chem., 2018, doi: 10.21580/wjc.v2i2.3105.

[5] M. Hardoko, "Aktivitas Antioksidan Dan Karakteristik Cuka Buah Mangrove Pedada (Sonneratia alba)," JFMR-Journal Fish. Mar. Res., 2019, doi: 10.21776/ub.jfmr.2019.003.03.6.

[6] S. Palimbong, "Pengaruh Konsentrasi Acetobacter aceti Dan Lama Fermentasi Terhadap Total Asam Cairan Fermentasi Pepaya Burung (Carica papaya , L .)," J. Sains Dan Teknol. Pangan, 2017.

[7] I. Nurika and N. Hidayat, "Pembuatan Asam Asetat dari Air Kelapa Secara Fermentasi Kontinyu Menggunakan Kolom Bio-Oksidasi,” J. Teknol. Pertan., 2001.

[8] A. Sasongko and B. Gotama, "Hidrolisis Limbah Kulit Nanas dengan Asam Asetat Menggunakan Metode Ultrasound-Assisted Acid Hydrolysis (UAAH) untuk Produksi Oligosakarida,” J. Sains Terap., 2019, doi: 10.32487/jst.v5i2.747.

[9] A. S. Sandika and S. R. Muria, "Fermentasi Kulit Nanas Menjadi Bioetanol Menggunakan Zymomonas Mobilis Dengan Variasi Pemekatan Medium Dan Waktu Fermentasi," Jom F Tek., 2017.

[10] D. Fahmi, B. Susilo, and W. A. Nugroho, "Pemurnian etanol hasil fermentasi kulit nanas (Ananas comosus L. Merr) dengan menggunakan distilasi vakum,” J. Keteknikan Pertan. Trop. Dan Biosist., 2014.

[11] Badan Pusat Statistik, "Statistik Tanaman Buah-buahan dan Sayuran Tahunan Indonesia," 2017.

[12] S. Wijana, A. Kumalaningsih, and U. Setyowati, "Optimailsasi Penambahan Tepung Kulit Nanas dan Proses Fermentasi pada Pakan Ternak terhadap Peningkatan Kualitas Nutrisi," Universitas Brawijaya, Malang, 1991. 
[13] P. Putra, "Pemanfaatan Nanas (Ananas Comosus) Sebagai Bahan Baku Pembuatan Bioetanol Dengan Metode Sakarifikasi Dan Fermentasi Serentak,” J. Biopropal Ind., 2011.

[14] J. Teknologi, H. Pertanian, F. Sains, G. Mada, Y. Jl, and B. Yogyakarta, “(IJHS) Indonesian Journal of Halal science, Vol.001, No.01, pp 12-17. 2019

[15] I. B. G. Awidyanata, G. . Ganda Putra, and L. P. Wrasiati, "Pengaruh Penambahan Ragi Tape dan Waktu Fermentasi Hasil Samping Cairan Pulpa terhadap Karakteristik Mutu Cuka Kakao (Theobroma cacao L.)," J. Rekayasa Dan Manaj. Agroindustri, vol. 8, no. 2, p. 177, 2020, doi: 10.24843/jrma.2020.v08.i02.p03.

[16] A. Mu, “済無No Title No Title,” J. Chem. Inf. Model., vol. 53, no. 9, pp. 1689-1699, 2019, doi: 10.1017/CBO9781107415324.004.

[17] N. Rachmawati, F. A. Nurlaily, and B. D. Wijatniko, "Pengaruh Waktu Fermentasi dan Penambahan Konsentrasi Inokulum (Acetobacter Aceti) terhadap Kualitas Asam Cuka dari Buah Kersen (Muntingia Calabura L)," Indones. J. Halal Sci., vol. 001, no. 01, pp. 12-17, 2019.

\section{Profil Penulis:}

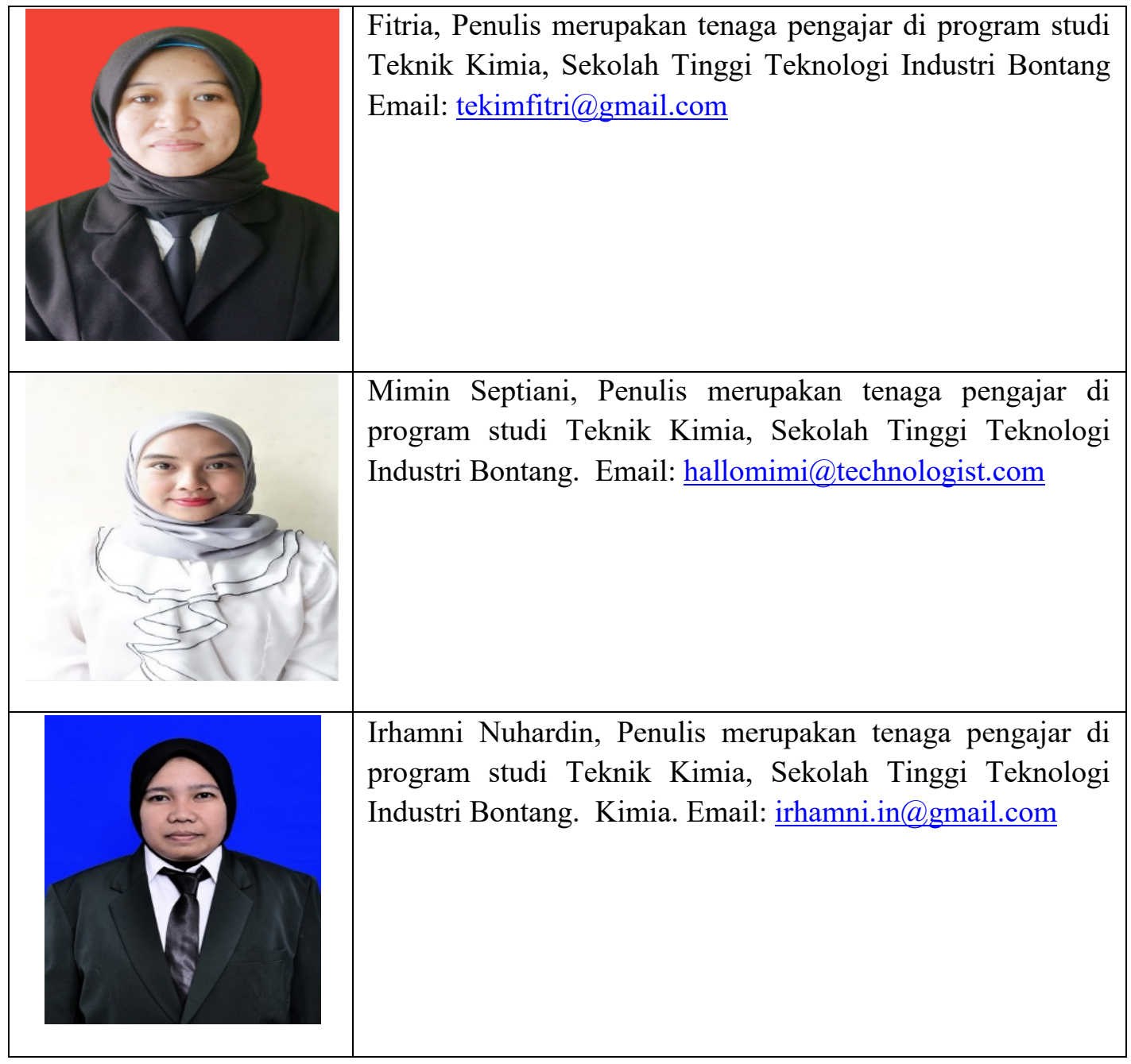

